\title{
PENGARUH VOLUME URIN TERHADAP PEMERIKSAAN SEDIMEN URIN PADA PASIEN INFEKSI SALURAN KEMIH (ISK)
}

\author{
Tadjuddin Naid, Fitriani Mangerangi, Muldhaniah Arsyad
}

Fakultas Farmasi Universitas Hasanuddin Makassar

Email : tadjuddinnaid@yahoo.co.id.

\begin{abstract}
The research about effect of urine volume to urine sediment examination in patient with Urinary Tract Infection (UTI) at Wahidin Sudirohusodo hospital was performed. This research aimed to find out the volume urine effect to urine sediment examination in Urinary Tract Infection (UTI) so as to improve the diagnostic a laboratory. This research used laboratorial eksperimental method with total samples are 30 consist of 13 male (43,3\%) and 17 female (56,7\%). Microscopically sample examination used Shih-Yung method with during urine with comparative volume 12 $\mathrm{ml}, 10 \mathrm{ml}$, and $8 \mathrm{ml}$. This research showed mean total urine sediment in volume 12

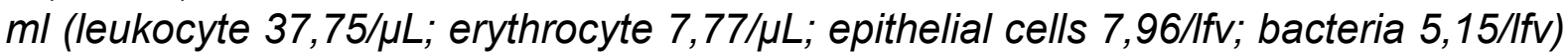
in volume $10 \mathrm{ml}$ (leukocyte 22,67/ $\mu \mathrm{L}$; erythrocyte 4,48/ $\mu \mathrm{L}$; epithelial cells 4,35/Ifv;

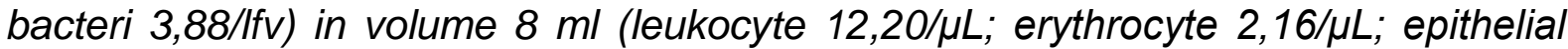
cells 2,50/ffv; bacteria 2,08//fv) from One Way Anova statistic test get $P$ value = $0,000 \quad(<0,05)$ showed there is significant different between urine sediment used volume $12 \mathrm{ml}, 10 \mathrm{ml}$, and $8 \mathrm{ml}$. From the result can be concluded that there is an effect of urine volume to urine sediment test in patient with UTI and volume $10 \mathrm{ml}$ as smallest urine volume can give an accurate result.
\end{abstract}

Key words: Urine volume, urine sediment, urinary tract infection, Shih-Yung method

\section{PNDAHULUAN}

Infeksi Saluran Kemih (ISK) adalah infeksi akibat berkembangnya mikroorganisme patogen di dalam saluran kemih. Infeksi saluran kemih dapat dipastikan bila terdapat pertumbuhan mikroorganisme sebanyak $>105$ dalam setiap mikroliter urin. Faktor predisposisi yang memudahkan terjadinya ISK antara lain sumbatan saluran kemih akibat kelainan anatomi dan struktur saluran kemih dan batu saluran kemih. Infeksi saluran kemih dilaporkan berada pada urutan kedua morbiditas penyakit infeksi, sesudah infeksi saluran nafas $(1,2,3)$.

ISK simtomatik terdapat bakteriuria disertai gejala klinik, dibagi menjadi dua bagian yaitu infeksi saluran kemih bagian atas (pielonefritits) dengan gejala utama demam, nyeri di atas tulang pubis serta sakit pinggang dan infeksi yang terbatas pada saluran kemih bagian bawah (sistitis) dengan gejala utama 
Pengaruh Volume Urin Terhadap Pemeriksaan Sedimen Urin Pada Pasien Infeksi Saluran Kemih (ISK)

berupa gangguan pengeluaran urin seperti disuria, polakisuria, kencing mengedan, gatal dan panas saat miksi serta timbul rasa sakit. Pielonefritis dan sistitis bisa terjadi bersamaan $(2,4,5)$.

Pada bayi baru lahir angka kejadian ISK berkisar antara 1,0 $2,4 \%$ dengan perbandingan antara bayi laki-laki dan perempuan antara 2,8:1 sampai 5,8 - 1, sampai usia 1 tahun proporsi kejadian ISK pada anak laki laki masih lebih tinggi daripada anak perempuan, tetapi di atas umur 1 tahun rasio ini menjadi terbalik dengan sangat mencolok dapat mencapai 1:10 (6). Dalam menentukan diagnosis, mengendalikan penyakit dan memantau pengobatan atau jalannya penyakit, para klinisi membutuhkan tes laboratorium, yaitu pemeriksaan sampel yang diperoleh dari penderita /pasien. Urinalisis merupakan salah satu bagian dari pemeriksaan laboratorium tersebut (7).

Urinalisis adalah pemeriksaan sampel urin secara makroskopis, kimia, dan mikroskopik. Tes makroskopis meliputi warna, kejernihan, $\mathrm{pH}$, berat jenis, bau, dan pengukuran volume. Tes mikroskopis yang diperiksa adalah sedimen urin dengan menggunakan mikroskop, sedangkan tes kimia dilakukan dengan menggunakan carik celup yang dilakukan secara manual maupun dengan menggunakan alat urin analyzer. Adapun tes khusus meliputi tes biakan urin, protein kualitatif 24 jam, hemosiderin urin, oval fat bodies, dan lain - lain sesuai kebutuhan khusus (8).

Sedimen urin adalah unsurunsur yang tidak larut di dalam urin yang berasal dari darah, ginjal, dan saluran kemih seperti eritrosit, lekosit, sel epitel, torak, bakteri, kristal, jamur dan parasit. Tes sedimen urin atau tes mikroskopis dipergunakan untuk mengidentifikasi unsur-unsur sedimen sehingga dipakai untuk mendeteksi kelainan ginjal dan saluran kemih, selain itu tes sedimen urin dapat juga dipakai untuk memantau perjalan penyakit ginjal dan saluran kemih setelah pengobatan (8).

Tes sedimen urin dapat menggunakan metode Shih-Yung yang merupakan metode penentuan sedimen urin yang menunjukkan ketelitian dan ketepatan yang lebih baik dibandingkan dengan cara semi kuantitatif, mengurangi penularan penyakit karena penggunaan tabung sentrifus, kamar hitung sekali pakai (disposible). Selain itu, metode ShihYung memberikan pelaporan secara kuantitatif. Pada tes sedimen urin 
Pengaruh Volume Urin Terhadap Pemeriksaan Sedimen Urin Pada Pasien Infeksi Saluran Kemih (ISK)

volume sampel urin yang dibutuhkan menurut standar adalah $12 \mathrm{ml}$, setelah disentifugasi secara otomatis tersisa $\pm 0,6 \mathrm{ml}$ sedimen urin (8).

Pembentukan urin di dalam nefron melalui 3 fase yaitu; pertama, ultrafiltrasi yang menghasilkan urin primer. Kedua, reabsorpsi komponenkomponen bermolekul kecil. Ketiga sisa dari penyerapan dialirkan ke papila renalis dan diekskresikan. Oliguria (volume urin berkurang) ditemukan pada keadaan antara lain demam, glomerulonefritis akut, gagal ginjal kronis dan infeksi saluran kemih $(9,10)$.

Pasien ISK yang mengalami gangguan pengeluaran urin dan oliguria kadang sulit memenuhi volume sampel urin yang sesuai standar untuk tes sedimen urin. Terkadang petugas laboratorium masih kurang peduli akan hal ini sehingga volume sampel urin yang digunakan tidak sesuai standar.

\section{METODE PENELITIAN}

Jenis Penelitian

Jenis penelitian ini

menggunakan desain eksperimental laboratorium.

\section{Lokasi dan Waktu Penelitian}

Lokasi penelitian dilakukan di RSUP Dr.Wahidin Sudirohusodo
Makassar. Waktu penelitian dimulai pada 10 April - 20 Juni 2012

\section{Populasi Penelitian}

Polupasi pada penelitian ini adalah semua penderita (ISK) Infeksi Saluran Kemih yang dirawat di RSUP Dr.Wahidin Sudirohusodo Makassar tahun 2012

\section{Sampel}

Sampel pada penelitian adalah semua populasi terjangkau yang memenuhi kriteria penelitian yang mengajukan permintaas tes sedimen urin di RSUP Dr.Wahidin Sudirohusodo Makassar. Besar sampel dihitung dengan menggunakan rumus Simple Random Sampling, yang hasilnya adalah sebesar 30 orang.

\section{Kriteria Inklusi}

1. Pasien yang mengajukan permintaan tes sedimen urin di Laboratorium RSUP Dr.Wahidin Sudirohusodo Makassar dan didiagnosa oleh dokter sebagai penderita ISK.

2. Usia dewasa $\geq 15$ tahun

3. Jenis kelamin laki-laki dan perempuan

\section{Kriteria Eksklusi}

1. Penderita kesulitan mengeluarkan urin kurang dari yang ditentukan.

2. Penderita yang sedang mengalami menstruasi. 
Pengaruh Volume Urin Terhadap Pemeriksaan Sedimen Urin Pada Pasien Infeksi Saluran Kemih (ISK)

3. Pasien yang sedang mengkonsumsi obat-obatan yang dapat mengganggu warna urin seperti rifampisin

4. Menolak dijadikan objek penelitian

\section{Alat dan Bahan}

Alat yang digunakan adalah kamar hitung Shih-Yung, pipet tetes plastik berukuran $1 \mathrm{ml}$, wadah steril penampung urin, mikroskop, sentrifus swing bucket rotor, rak tabung, tabung khusus urin yang terbuat dari plastik dan bertutup. Sedangkan bahan yang digunakan adalah urin sewaktu dan pewarna Stenheimer Malbin.

\section{Prosedur Kerja}

\section{Pengambilan Urin}

Cara pengambilan sampel urin sewaktu yang dilakukan oleh pasien:

1. Tangan dicuci menggunakan sabun kemudian dikeringkan dengan handuk atau tissue.

2. Urin dikeluarkan, aliran yang pertama dibuang, aliran urin selanjutnya ditampung dalam wadah yang sudah disediakan.

3. Urin selesai ditampung sebelum aliran habis

4. Wadah ditutup rapat dan segera dibawa ke laboratorium untuk segera diperiksa.

\section{Perlakuan terhadap sampel}

Urin pancaran yang sudah ditampung ke dalam wadah steril, dibagi ke dalam 3 tabung plastik tertutup, masing-masing $8 \mathrm{ml}, 10 \mathrm{ml}$ dan $12 \mathrm{ml}$.

\section{Tes Sedimen Urin Metode Shih-} Yung

Sampel urin yang telah dimasukkan ke dalam masing-masing tabung plastik dan ditutup dengan penutupnya. Kemudian, di sentrifugasi 1500 rpm selama 5 menit. Dibuang supernatan dengan cara membalikkan tabung dan secara otomatis urin tersisa $\pm 0,6 \mathrm{ml}$ sebagai sedimen. Ditambahkan 1 tetes pewarna sedimen lalu dilakukan resuspensi sedimen urin dengan cara mengetukkan jari perlahan pada dinding tabung. Diteteskan 1 tetes sedimen dengan menggunakan pipet penetes ke dalam kamar hitung. Dilakukan pemeriksaan sedimen di bawah mikroskop, unsur sedimen dihitung pada 4 bidang sedang dengan menggunakan pembesaran $10 \times$ untuk menghitung silinder dan pembesaran $40 \times$ untuk menghitung sel.

Cara pelaporan hasil pemeriksaan sedimen urin :

1. Leukosit : Normal $:<10 / \mu \mathrm{L}$

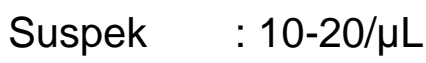
Abnormal $:>20 / \mu \mathrm{L}$

2. Eritrosit : Normal $:<3 / \mu \mathrm{L}$ 
Pengaruh Volume Urin Terhadap Pemeriksaan Sedimen Urin Pada Pasien Infeksi Saluran Kemih (ISK)

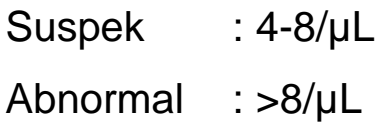

3. Sel Epitel $:+1 \longrightarrow: 4 /$ LPB

$+2 \longrightarrow: 5-9 /$ LPB

$+3 \longrightarrow: 10-29 /$ LPB

$+4 \longrightarrow:>30 / L P B$

$+5 \longrightarrow: 1 / 2 / \mathrm{LPB}$

4. Bakteri : 0-5/LPB

\section{HASIL PENELITIAN}

Telah dilakukan tes mikroskopik atau tes sedimen urin terhadap 30 sampel ISK untuk melihat jumlah leukosit, eritrosit, sel epitel, dan bakteri dengan menggunakan perbandingan volume sampel urin yaitu volume $8 \mathrm{ml}$, $10 \mathrm{ml}$, dan $12 \mathrm{ml}$ pada pasien Infeksi saluran kemih di RSUP Dr.Wahidin sudirohusodo Makassar pada tanggal 10 April sampai 20 Juni 2012.
Hasil penelitian yang telah dilaksanakan maka didapat data dasar penelitian yaitu 13 orang laki-laki $(43,3 \%)$ dan 17 orang perempuan $(56,7 \%)$ yang mengalami ISK. Berdasarkan kelompok umur, kelompok umur usia 25-50 tahun dan $>50$ tahun merupakan kelompok umur terbanyak mengalami ISK, sedangkan kelompok umur < 25 tahun merupakan kelompok yang paling sedikit mengalami ISK.

Hasil rata-rata jumlah sedimen urin pada pemeriksaan secara mikroskopik terhadap sampel urin pasien yang mengalami ISK dengan perbedaan volume sampel urin $8 \mathrm{ml}$, $10 \mathrm{ml}$, dan $12 \mathrm{ml}$ dapat dilihat pada tabel di bawah ini :

Tabel 1. Hasil rata-rata sedimen urin pada volume yang berbeda pada pasien ISK

\begin{tabular}{cccccc}
\hline \multirow{2}{*}{ NO } & \multirow{2}{*}{ Volume } & \multicolumn{4}{c}{ Rata-rata hasil tes sedimen urin } \\
\cline { 3 - 6 } & & Leukosit & Eritrosit & Sel epitel & Bakteri \\
\hline \multirow{2}{*}{1} & \multirow{2}{*}{$12 \mathrm{ml}$} & $37,75 / \mu \mathrm{l}$ & $7,77 / \mu \mathrm{l}$ & $7,96 / \mathrm{pb}$ & $5,15 / \mathrm{ppb}$ \\
& \multirow{2}{*}{2} & $(\mathrm{SD}=19,60)$ & $(\mathrm{SD}=5,27)$ & $(\mathrm{SD}=4,40)$ & $(\mathrm{SD}=2,78)$ \\
& \multirow{2}{*}{$10 \mathrm{ml}$} & $22,67 / \mu \mathrm{l}$ & $4,48 / \mu l$ & $4,35 / \mathrm{pb}$ & $3,88 / \mathrm{pb}$ \\
\multirow{2}{*}{3} & \multirow{2}{*}{$8 \mathrm{ml}$} & $(\mathrm{SD}=14,08)$ & $(\mathrm{SD}=3,78)$ & $(\mathrm{SD}=2,69)$ & $(\mathrm{SD}=1,93)$ \\
& & $(\mathrm{SD}=6,75)$ & $(\mathrm{SD}=1,62)$ & $(\mathrm{SD}=1,90)$ & $(\mathrm{SD}=0,79)$ \\
\hline
\end{tabular}

Untuk melihat perbandingan hasil pemeriksaan sedimen urin secara mikroskopik dengan volume sampel urin $8 \mathrm{ml}, 10 \mathrm{ml}$, dan $12 \mathrm{ml}$, maka dilakukan uji statistik menggunakan uji
One Way Anova dengan tingkat kepercayaan 95\% dengan bantuan SPSS 16 for windows, yang hasil pengujiannya dapat dilihat pada tabel di bawah ini : 
Pengaruh Volume Urin Terhadap Pemeriksaan Sedimen Urin Pada Pasien Infeksi Saluran Kemih (ISK)

\begin{tabular}{ccccc}
\hline $\begin{array}{c}\text { Parameter pemeriksaan } \\
\text { sedimen urin }\end{array}$ & $\begin{array}{c}\text { Variasi volume sampel } \\
\text { urin }\end{array}$ & F & $\begin{array}{c}\text { Signifikan } \\
(\mathbf{p})\end{array}$ & $\boldsymbol{\alpha}$ \\
\hline \multirow{2}{*}{ Leukosit } & $12 \mathrm{ml}$ & & & \\
& $10 \mathrm{ml}$ & 23,290 & 0,000 & 0,05 \\
$8 \mathrm{ml}$ & $12 \mathrm{ml}$ & & & \\
\hline \multirow{2}{*}{ Eritrosit } & $10 \mathrm{ml}$ & 11,621 & 0,000 & 0,05 \\
& $8 \mathrm{ml}$ & & & \\
\hline \multirow{2}{*}{ Sel epitel } & $12 \mathrm{ml}$ & & & \\
& $10 \mathrm{ml}$ & 14,669 & 0,000 & \\
\hline & $8 \mathrm{ml}$ & & & \\
Bakteri & $12 \mathrm{ml}$ & & & \\
\hline
\end{tabular}

Pembacaan hasil statistik menggunakan One Way Anova berdasarkan tingkat signifikan dengan hipotesis sebagai berikut :

HO : Tidak ada perbedaan jumlah unsur sedimen dengan penggunaan variasi volume sampel urin

H1 : Ada perbedaan jumlah unsur sedimen dengan penggunaan variasi volume sampel urin

Hasil penentuan yaitu jika nilai signifikan $(\mathrm{P})>0,05$ maka $\mathrm{HO}$ diterima, dan jika nilai signifikansi $(P)<0,05$ maka $\mathrm{H} 1$ diterima.

\section{PEMBAHASAN}

Dilakukan

pemeriksaan

mikroskopik pada pasien Infeksi Saluran Kemih (ISK) untuk melihat perbandingan jumlah unsur sedimen dengan menggunakan volume sampel urin $12 \mathrm{ml}, 10 \mathrm{ml}$, dan $8 \mathrm{ml}$ di RSUP
Wahidin Sudirohusodo yang dilakukan terhadap 30 sampel.

Dari hasil penelitian tentang pengaruh volume sampel urin terhadap pemeriksaan sedimen urin pada pasien ISK diperoleh hasil karateristik populasi berdasarkan jenis kelamin, terdapat 13 orang laki-laki $(56,70 \%)$ dan 17 orang perempuan $(43,30 \%)$ yang mengalami ISK. Dari data tersebut terlihat bahwa kasus ISK lebih banyak terjadi pada kelompok perempuan dibanding kelompok lakilaki. Angka kejadian ISK pada kelompok perempuan yang lebih tinggi karena beberapa faktor, yaitu uretra wanita lebih pendek daripada pria, dan kehamilan. Penggunaan WC umum yang kurang bersih dapat menyebabkan terjadinya penularan penyakit melalui alat kelamin terutama bakteri dan jamur. Selain itu pada saat 
Pengaruh Volume Urin Terhadap Pemeriksaan Sedimen Urin Pada Pasien Infeksi Saluran Kemih (ISK)

dilakukan penelitian ternyata kelompok perempuan lebih banyak yang datang melakukan pemeriksaan urinalisis.

Karateristik

populasi

berdasarkan umur, yaitu pada kelompok umur 25 - 50 tahun dan kelompok umur $>50$ tahun merupakan kelompok yang paling banyak mengalami ISK. Hal ini terjadi karena pada umur tersebut sistem imun tubuh terjadi penurunan karena beberapa hal antara lain penuaan dan pemakaian kontrasepsi, sehingga bakteri dengan mudah tumbuh dan berkembang menyebabkan ISK.

Tes sedimen urin digunakan untuk mengidentifikasi jenis atau unsur sedimen urin yaitu eritrosit, leukosit, sel epitel, dan bakteri. Tes ini digunakan untuk mendeteksi infeksi saluran kemih dan memantau perjalanan penyakit ISK setelah pengobata. Pada penelitian ini tes sedimen urin menggunakan metode Shih-Yung. Metode ini dapat menunjukkan ketelitian dan ketepatan lebih akurat, dapat mengurangi kontaminasi karena tabung sentifus, kamar hitung dan pipet yang disposible sehingga hasil yang diperoleh lebih baik.

Dari hasil penelitian diketahui bahwa pada volume $12 \mathrm{ml}$ nilai ratarata leukosit $=37,75 / \mu l \quad(S D=19,599)$, eritrosit $=7,77 / \mu \mathrm{l} \quad(\mathrm{SD}=5,270)$, sel epitel $=7,96 / \mathrm{pb} \quad(S D=4,404)$, bakteri $5,15 / \mathrm{lpb}(\mathrm{SD}=2,777)$. Pada volume 10 $\mathrm{ml}$ nilai rata-rata leukosit $22,67 / \mu \mathrm{l}$ $(\mathrm{SD}=14,079)$, eritrosit $=4,48 / \mu \mathrm{l}$ $(\mathrm{SD}=3,776)$, sel epitel $=4,35 / \mathrm{pb}$ $(\mathrm{SD}=2,69), \quad$ bakteri $\quad 3,88 / \mathrm{pb}$ $(\mathrm{SD}=1,928)$, dan volume $8 \mathrm{ml}$ nilai rata-rata leukosit $12,20 / \mu \mathrm{l}(\mathrm{SD}=6,754)$, eritrosit $=2,16 / \mu \mathrm{l} \quad(\mathrm{SD}=1,624)$, sel epitel $=2,50 / \mathrm{pb} \quad(\mathrm{SD}=1,897)$, bakteri 2,08/lpb (SD=0,793). Hal ini menunjukkan adanya perbedaan yang bermakna hasil pemeriksaan unsur sedimen dari ketiga perbedaan volume dan terjadi penurunan hasil rata-rata pada volume $10 \mathrm{ml}$ dan $8 \mathrm{ml}$.

Analisis statistik menggunakan uji One Way Anova menunjukkan pemeriksaan sedimen urin leukosit didapatkan $F$ hitung 23,290 dengan signifikan $(P)$ 0,000 $<0,05$ maka $\mathrm{H} 1$ diterima, yang berarti ada perbedaan yang bermakna jumlah leukosit pada ketiga perbandingan volume sampel urin. Sedimen urin eritrosit didapatkan $F$ hitung 11,621 dengan signifikan (P) $0,000<0,05$ maka $\mathrm{H} 1$ diterima berarti ada perbedaan yang bermakna jumlah eritrosit pada ketiga perbandingan volume sampel urin. Hal ini juga berlaku pada sel epitel dan bakteri yaitu H1 diterima yang berarti ada perbedaan yang bermakna dengan 
Pengaruh Volume Urin Terhadap Pemeriksaan Sedimen Urin Pada Pasien Infeksi Saluran Kemih (ISK)

masing-masing $F$ hitung sel epitel 14,669 dengan signifikan $(P) 0,000<$ 0,05 dan $F$ hitung bakteri 7,603 dengan signifikan $0,001<0,05$.

Perbandingan volume sampel urin yaitu $12 \mathrm{ml}, 10 \mathrm{ml}$,dan $8 \mathrm{ml}$ berpengaruh terhadap hasil pemeriksaan sedimen urin karena hal ini berpengaruh pada pengumpulan unsur sedimen pada dasar tabung setelah disentrifus, oleh sebab itu penggunaan volume sampel urin pada tes sedimen urin harus sesuai yang di anjurkan yaitu $12 \mathrm{ml}$. Penggunaan volume sampel urin terkecil yang masih bisa ditoleransi dan masih memberikan hasil akurat yaitu $10 \mathrm{ml}$. Volume sampel urin untuk tes sedimen urin tidak boleh kurang dari volume 10 $\mathrm{ml}$ karena akan memberikan hasil negatif palsu yang terlihat pada hasil uji statistik tes sedimen urin menggunakan volume $8 \mathrm{ml}$ terjadi penurunan nilai rata-rata mendekati nilai normal. Hal ini didapatkan juga pada penelitian terdahulu oleh Dian Rahayu tahun 2005 dengan menggunakan 10 sampel pasien chekup menilai ada pengaruh volume sampel urin pada tabung terhadap nilai sedimen leukosit dan eritrosit.

Penelitian ini dapat dilanjutkan dengan kultur urin atau biakan urin untuk melihat jenis mikroorganisme atau bakteri patogen yang terdapat pada urin pasien penyebab ISK, sehingga pemberian antibiotika nantinya lebih baik karena langsung ditujukan pada bakteri patogen tersebut.

\section{KESIMPULAN}

Berdasarkan hasil penelitian yang telah dilakukan terhadap 30 orang subjek pasien ISK di RS Wahidin Sudirohusodo Makassar dapat disimpulkan bahwa terdapat perbedaan yang bermakna hasil pemeriksaan sedimen urin menggunakan volume sampel urin 8 $\mathrm{ml}, 10 \mathrm{ml}$, dan $12 \mathrm{ml}$ dengan demikian ada pengaruh volume urin terhadap hasil tes sedimen urin.

Penggunaan volume sampel urin terkecil yang masih bisa di toleransi dan memberikan hasil akurat yaitu $10 \mathrm{ml}$. Penggunaan volume sampel urin tidak boleh $<10 \mathrm{ml}$ karena hasil pemeriksaan yang diperoleh tidak akurat dan cenderung memberikan hasil negatif palsu.

\section{DAFTAR PUSTAKA}

1. Harrison IB. Prinsip-Prinsip IImu Penyakit Dalam. Edisi 13. Buku Kedokteran. EGC. Jakarta. 2000. Hal 616-620

2. Alatas H. Diagnosa dan Tatalaksana Infeksi Saluran Kemih. Ed.Hot Topics in Pediatrics II. Balai Penerbit FKUI. Jakarta. 2002. 
Pengaruh Volume Urin Terhadap Pemeriksaan Sedimen Urin Pada Pasien Infeksi Saluran Kemih (ISK)

3. Tambunan T. Infeksi Saluran Kemih. Balai Penerbit FKUI. Jakarta. 2006.

4. Rusdidjas, Ramayanti R. Infeksi Saluran Kemih. Balai Penerbit FKUI. Jakarta. 2002. Hal 127

5. Wijaya, kusuma B. Bebas Penyakit ginjal dan Saluran kemih. Pustaka Bunda. Jakarta. 2009. Hal 53.

6. Elder, J.S. Urinary Tract Infections. In: Behman, R.E., Kliegman, R.M., Arvin, A.M.,Eds. Nelson textbook of pediatrics; $17^{\text {th }}$ Ed. WB Saunders Co., Philadelphia. 2003.

7. Hardjoeno H. Interpretasi Hasil Tes Laboratorium Diagnostik Edisi 5.
Lembaga penerbitan Universitas Hasanuddin. 2003. Hal 40, 129.

8. Hardjoeno H, Fitriani. Substansi dan Cairan Tubuh. Ed. Baru. Lembaga Penerbitan Universitas Hasanuddin. Makassar. 2007. Hal 1-50.

9. Koolman J, Klaus-Heinrich R. Atlas berwarna dan teks Biokimia. 2000. Penerbit hipocrates. Jakarta. Hal 290-291.

10. Soewoto $H$. Biokimia Eksperimen laboratorium. Bagian Biokimia FKUI. Widya Medika. Jakarta. 2001. Hal 170. 